\title{
Differentiation of human osteosarcoma 3AB-OS stem-like cells in derivatives of the three primary germ layers as a useful in vitro model to develop several purposes
}

\author{
Riccardo Di Fiore $^{1^{*}}$, Rosa Drago-Ferrante ${ }^{1^{*}}$, Antonella D'Anneo $^{1}$, Anna De Blasio ${ }^{1}$, \\ Andrea Santulli ${ }^{2}$, Concetta Messina ${ }^{2}$, Daniela Carlisi ${ }^{3}$, Giovanni Tesoriere ${ }^{4}$, Renza Vento ${ }^{1,4 \#}$ \\ ${ }^{1}$ Laboratory of Biochemistry, Department of Biological, Chemical and Pharmaceutical Sciences and Technologies, Polyclinic, University \\ of Palermo, Palermo, Italy; ${ }^{\#}$ Corresponding Author: renza.vento@unipa.it \\ ${ }^{2}$ Department of Earth and Marine Sciences, University of Palermo, Palermo, Italy \\ ${ }^{3}$ Section of Biochemical Sciences, Department of Experimental Biomedicine and Clinical Neurosciences, Polyclinic, University of \\ Palermo, Palermo, Italy \\ ${ }^{4}$ Institute for Cancer Research and Molecular Medicine and Center of Biotechnology-College of Science and Biotechnology, Temple \\ University, Philadelphia, USA
}

Received 17 January 2013; revised 17 February 2013; accepted 17 March 2013

Copyright (C) 2013 Riccardo Di Fiore et al. This is an open access article distributed under the Creative Commons Attribution License, which permits unrestricted use, distribution, and reproduction in any medium, provided the original work is properly cited.

\section{ABSTRACT}

A number of solid tumors contain a distinct subpopulation of cells, termed cancer stem cells (CSCs) which represent the source for tissue renewal and hold malignant potential and which would be responsible for therapy resistance. Today, the winning goal in cancer research would be to find drugs to kill both cancer cells and cancer stem cells, while sparing normal cells. Osteosarcoma is an aggressive pediatric tumor of growing bones that, despite surgery and chemotherapy, is prone to relapse. We have recently selected from human osteosarcoma MG63 cells a cancer stem-like cell line (3AB-OS), which has unlimited proliferative potential, high levels of stemness-related markers, and in vivo tumorforming capacity in xenograft assays. Here, we have shown that $3 A B-O S$ cells can differentiate in vitro into endoderm-, mesoderm- and ectodermderived lineages. Cell differentiation is morphological, molecular and functional. We propose that this model system of $3 A B-O S$ differentiation in vitro might have a number of useful purposes, among which the study of molecular mechanisms of osteosarcoma origin, and the analysis of factors involved in specification of the various cell lineages. We still do not know either what are the shared and distinguishing charac-

${ }^{*}$ These authors contributed equally to this work. ters between CSCs and normal stem cells, or what is the reason why the cancer stem cells, like the normal stem cells, have the ability to differentiate toward the derivatives of the primary germ layers. It is possible that each of the differentiation capability may be exploited by CSCs to supply their needs of growing and surviving in hostile microenvironment.

Keywords: Human Osteosarcoma; Cancer Stem Cells; In Vitro Differentiation; Pluripotentiality

\section{INTRODUCTION}

Osteosarcoma is the most common non-hematologic malignancy of bone in children and adults, consisting of malignant cells that produce immature bone and is characterized by osteoid formation within the tumor $[1,2]$. There are about 2500 new cases of osteosarcoma diagnosed each year in the US with about one half occurring in children and adolescents, younger than 20 years of age. It is a highly aggressive tumor exhibiting clinical, histologic, and molecular heterogeneity. The tumor, which in about $80 \%$ of cases occurs at sites of rapid bone growth (the metaphyses of long bones), has an initial peak incidence in the pediatric and early adult population and a second peak incidence in later adult life [3]. The current standard chemotherapy regimen, which includes cisplatin, doxorubicin and methotrexate, provides only $65 \%-70 \%$ long-term disease-free survival for osteosar- 
coma patients without metastasis, and there is no established second-line chemotherapy for relapsed osteosarcoma [4]. Thus, there is an urgent need to identify new therapeutic strategies to improve the clinical outcome of patients with osteosarcoma.

It has been demonstrated that a number of solid tumors contains a distinct subpopulation of cells, termed cancer stem cells (CSCs), which represent the source for tissue renewal and hold malignant potential and which would be responsible for therapy resistance [5-7]. It has been suggested that a successful cure of cancer should require CSCs eradication [8-10].

Previously, we have demonstrated that in human osteosarcoma MG63 cells aberrant gene expression keeps $\mathrm{Rb}$ protein constitutively inactivated through hyperphosphorylation and this promotes uncontrolled cell proliferation [11]. Brief-term treatment of MG63 cells with 3aminobenzamide (3AB), a potent inhibitor of poly (ADPribose) polymerase (PARP), induced morphological and biochemical features of osteocyte differentiation, accompanied by an increase in the hypophosphorylated/active form of $\mathrm{Rb}$, with downregulation of gene products required for proliferation (cyclin D1, $\beta$-catenin, c-Jun, c-Myc and Id2) and upregulation of those implicated in the osteoblast differentiation (p21/Waf1, osteopontin, osteocalcin, type I collagen, N-cadherins and alkaline phosphatase) [12]. Our study suggested that in MG63 cells, 3AB treatment may induce a remodeling of chromatin with a reprogramming of gene expression and the activation of differentiation. However, prolonged treatment (about 100 days) of MG63 cells with $3 \mathrm{AB}$ induced osteocyte death accompanied by a progressive enrichment of a new cell population. These cells, termed $3 \mathrm{AB}-\mathrm{OS}$, are a heterogeneous and stable cell population, which after $3 \mathrm{AB}$ withdrawal and serial passages (currently, more than 200) has retained its morphological and antigenic features. Overall, these cells exhibit a number of characters which suggested that they are CSCs and that allowed their patenting (Pluripotent cancer stem cells: their preparation and use. Renza Vento and Riccardo Di Fiore, Patent Appln. No. FI2008A000238, December 11, 2008). Indeed, 3ABOS cells possess a strong self-renewal ability and a high levels of cell cycle markers which account for G1-S/G2$\mathrm{M}$ phases progression. They can be reseeded unlimitedly without losing the proliferative potential, show a ATPbinding cassette transporter ABCG2-dependent phenotype with high drug efflux capacity, and a strong positivity for CD133, a marker for pluripotent stem cells. 3ABOS cells highly express genes required for maintaining stem cell state (Oct-3/4, h-TERT, nucleostemin, Nanog) and for inhibiting apoptosis (HIF-1, FLIP-L, Bcl-2, XIAP, IAPs and survivin) and grow in ultralow-attachment plates at a low density with a high sphere-formation efficiency [13]. 3AB-OS cells have been also characterized at genetic and molecular level, showing that they have a great chromosomal complexity and a large number of molecular abnormalities, which are characteristic of the most aggressive human cancers. Indeed, 3AB-OS cells have hypertriploid karyotype with 71 - 82 chromosomes. Comparing 3AB-OS CSCs to MG63 cells, we have identified 49 copy number variations, 3512 dysregulated genes and 189 differentially expressed miRNAs. Remarkably, the abnormalities evidenced in 3AB-OS cells appear to be strongly congruent with abnormalities described in the literature in a large number of pediatric and adult osteosarcomas [14]. We have also shown that $3 \mathrm{AB}-$ OS cells penetrate matrigel with a 2.6-fold higher invasion ability than the parental MG63 cells (unpublished data), that they are tumorigenic and recapitulate in vivo (athymic mice xenograft) various features of human osteosarcoma, thereby representing a useful model system to test in vivo novel antitumor approaches against human osteosarcoma [15].

Here, we have extended our study by analysing $3 \mathrm{AB}$ OS pluripotency, namely we have studied the capability of $3 \mathrm{AB}-\mathrm{OS}$ cells to produce in vitro derivatives of the three primary germ layers.

\section{MATERIALS AND METHODS}

\subsection{Cell Cultures}

The human $3 \mathrm{AB}-\mathrm{OS}$ cancer stem cells have been produced in our laboratory [13]. 3AB-OS cells were cultured as monolayers in T-75 flask in Dulbecco's modified Eagle medium (DMEM), supplemented with 10\% (v/v) heat inactivated fetal bovine serum, $2 \mathrm{mM}$ L-glutamine, $100 \mathrm{U} / \mathrm{ml}$ penicillin and $50 \mu \mathrm{g} / \mathrm{ml}$ streptomycin (Euroclone, Pero-Italy) in a humidified atmosphere of $5 \% \mathrm{CO}_{2}$ in air at $37^{\circ} \mathrm{C}$. When cells grew to approximately $80 \%$ confluence, they were subcultured or harvested using $0.025 \%$ trypsin-EDTA (Life Technologies Ltd., Monza, Italy). Cell viability was tested by trypan blue exclusion (SigmaAldrich Srl, Milano, Italy).

\subsection{Morphological Observation}

Cell morphology was evaluated using a Leica DM IRB inverted microscope (Leica Microsystems Srl, Milano, Italy). Images were photographed and captured by a computer-imaging system (Leica DC300F camera and Adobe Photoshop for image analysis).

\subsection{Differentiation of $3 A B-O S$ Cells toward Endoderm-Derived Cell Lineages}

\subsubsection{Hepatogenic Differentiation}

The 3AB-OS were seeded at $1 \times 10^{4}$ cells $/ \mathrm{cm}^{2}$ in DMEM, supplemented with $10 \%(\mathrm{v} / \mathrm{v})$ heat inactivated fetal bovine serum, $2 \mathrm{mM}$ L-glutamine, $100 \mathrm{U} / \mathrm{ml}$ peni- 
cillin and $50 \mu \mathrm{g} / \mathrm{ml}$ streptomycin. The culture medium was changed $24 \mathrm{~h}$ later to Iscove's modified Dulbecco's medium (IMDM, Euroclone) containing $20 \mathrm{ng} / \mathrm{ml}$ epidermal growth factor (EGF), $20 \mathrm{ng} / \mathrm{ml}$ hepatocyte growth factor (HGF), $10 \mathrm{ng} / \mathrm{ml}$ basic fibroblast growth factor (bFGF) and $0.61 \mathrm{~g} / 1$ nicotinamide (all from Sigma-Aldrich) and the 3AB-OS cells were cultured for 4 days. Thereafter, the maturation step consisted of treatment with IMDM containing $20 \mathrm{ng} / \mathrm{ml}$ oncostatin M (OSM; Life Technologies Ltd.), $1 \mu \mathrm{mol} / 1$ dexamethasone (Sigma-Aldrich) and $1 \%$ insulin-transferrin-selenium premix (Life Technologies Ltd.) for 16 days. For each step, the culture medium was changed every 3 days [16].

\subsubsection{Urea Production Assay}

Urea concentrations within culture media were measured colometrically according to the manufacturer's instructions (Urea assay kit) after $24 \mathrm{~h}$ exposure of the differentiated cells to $6 \mathrm{mM} \mathrm{NH} 4 \mathrm{Cl}$ (all from Sigma-Aldrich) at various time-points throughout differentiation (days $0,5,10,15,20$ ) in five different samples. Culture media from undifferentiated 3AB-OS cells supplemented with $6 \mathrm{mM} \mathrm{NH} 4 \mathrm{Cl}$ were used as negative control.

\subsubsection{Staining for Glycogen Accumulation}

After $4 \%$ formaldehyde fixation, the 3AB-OS cells were incubated for $10 \mathrm{~min}$ in 1\% periodic acid (SigmaAldrich) and then washed with distilled water. Samples were then treated with Schiff's regent (Sigma-Aldrich) for $15 \mathrm{~min}$ and rinsed in deionized water $\left(\mathrm{dH}_{2} \mathrm{O}\right)$ for 5 $\mathrm{min}$. They were then counterstained with Gill 3's haematoxylin (Sigma-Aldrich) for $1 \mathrm{~min}$, rinsed in $\mathrm{dH}_{2} \mathrm{O}$ and assessed under a light microscope for glycogen accumulation [16].

\subsubsection{Bile Canaliculus Labeling}

Cells were incubated with $1 \mu \mathrm{g} / \mathrm{ml}$ fluorescein diacetate (Sigma-Aldrich) for 15 minutes at $37^{\circ} \mathrm{C}$ and then fixed with $4 \%$ formaldehyde for 20 minutes at $4^{\circ} \mathrm{C}$ [17]. Cells were examined on a Leica DM IRB microscope equipped for fluorescence, images were captured by a computer-imaging system (LeicaDC300F camera and Adobe Photoshop for image analysis).

\subsection{Differentiation of $3 A B-O S$ Cells toward Mesoderm-Derived Cell Lineages}

\subsubsection{Osteogenic Differentiation}

For osteogenic differentiation 3AB-OS were induced in 3 weeks by DMEM supplemented with 10\% FBS, 0.1 $\mu \mathrm{M}$ dexamethasone, $10 \mathrm{mM} \beta$-glycerophosphate and 50 $\mu \mathrm{M}$ ascorbate-phosphate (all from Sigma-Aldrich) [18]. Control cultures without the differentiation stimuli were maintained in parallel to the differentiation experiments and stained in the same manner. Medium was changed every 3 days for all differentiation assay.

\subsubsection{ALP Staining}

After rinsing monolayer cells with PBS, the cells were fixed in 3.7\% formaldehyde and $90 \%$ ethanol solution for $2 \mathrm{~min}$ and washed in PBS for $10 \mathrm{~min}$. Then, the cells were stained with fast 5-bromo-4-chloro-3-indolyl phosphate and nitroblue tetrazolium (BCIP/NBT) alkaline phophatase substrate (Prodotti Gianni, Milano, Italy) for $10 \mathrm{~min}$ at room temperature. The reaction was stopped by removing the substrate solution and washing with distilled water [19].

\subsubsection{Alizarin Red S Staining for Mineralized Matrix}

Cells were fixed with $70 \%$ ice-cold ethanol for $1 \mathrm{~h}$ at $-20^{\circ} \mathrm{C}$, and stained with $40 \mathrm{mM}$ alizarin red S (ARS; Sigma-Aldrich), $\mathrm{pH} 4.2$ for $10 \mathrm{~min}$ at room temperature [20].

\subsubsection{Adipogenic Differentiation}

For adipogenic differentiation 3AB-OS were induced for 3 weeks by DMEM supplemented with $10 \%, 1 \mu \mathrm{M}$ dexamethasone, $200 \mu \mathrm{M}$ indomethacin, $5 \mu \mathrm{g} / \mathrm{ml}$ insulin, $500 \mu \mathrm{M}$ isobutyl-methylxanthine (all from Sigma-Aldrich) [21]. Control cultures without the differentiation stimuli were maintained in parallel to the differentiation experiments and stained in the same manner. Medium was changed every 3 days for all differentiation assay.

\subsubsection{Oil Red O Staining}

For evidence of adipogenic differentiation, cells were tested for lipid granules using Oil Red O stain. Briefly, cells were fixed with $4 \%$ formaldehyde for $10 \mathrm{~min}$, washed with $60 \%$ isopropanol, and stained with Oil RedO-solution (in 60\% isopropanol, Sigma-Aldrich) for 20 $\mathrm{min}$ at room temperature. Cells were rinsed in $60 \%$ isopropanol followed by repeated washing with distilled water. Lipids appeared red [22].

\subsubsection{Cardiomyogenic Differentiation}

The $3 \mathrm{AB}-\mathrm{OS}$ were seeded at $1 \times 10^{4} \mathrm{cells} / \mathrm{cm}^{2}$ in DMEM supplemented with $10 \%(\mathrm{v} / \mathrm{v})$ heat inactivated fetal bovine serum, $2 \mathrm{mM}$ L-glutamine, $100 \mathrm{U} / \mathrm{ml}$ penicillin and $50 \mu \mathrm{g} / \mathrm{ml}$ streptomycin. The culture medium was changed $24 \mathrm{~h}$ later to cardiomyogenic differentiation medium (MDM) consisting of $60 \%$ DMEM-LG/28\% MCDB-201 (Sigma-Aldrich), $1 \%$ insulin-transferrinselenium premix (Life Technologies Ltd.), $50 \mathrm{mg} / \mathrm{ml}$ bovine serum albumin, and $0.47 \mu \mathrm{g} / \mathrm{ml}$ linoleic acid, $10^{-4} \mathrm{M}$ ascorbate phosphate, $10^{-9} \mathrm{M}$ dexamethasone (all from Sigma-Aldrich), $100 \mathrm{U} / \mathrm{ml}$ penicillin, $50 \mu \mathrm{g} / \mathrm{ml}$ streptomycin, and 10\% FBS for 18 days [23]. 


\subsubsection{Angiogenic Differentiation}

$3 \mathrm{AB}-\mathrm{OS}$ cells were induced to differentiate into endothelial cells by culturing the confluent cells in 6-well plates in high-glucose DMEM with 2\% FBS and 50 $\mathrm{ng} / \mathrm{ml}$ VEGF (Sigma-Aldrich) for 7 days [24]. Analysis of capillary formation was performed using Matrigel (CULTREX, Trevigen; TEMA ricerca S.r.l., Bologna, Italy) and capillary-like structures were observed by optical microscopy after $24 \mathrm{~h}$.

\subsubsection{Osteoclastogenic Differentiation}

$3 \mathrm{AB}-\mathrm{OS}$ were seeded at $1 \times 10^{4} \mathrm{cells} / \mathrm{cm}^{2}$ in DMEM, supplemented with $10 \%(\mathrm{v} / \mathrm{v})$ heat inactivated fetal bovine serum, $2 \mathrm{mM} \mathrm{L}$-glutamine, $100 \mathrm{U} / \mathrm{ml}$ penicillin and $50 \mu \mathrm{g} / \mathrm{ml}$ streptomycin. The culture medium was changed $24 \mathrm{~h}$ later to complete Minimun Essential Medium (MEM, Euroclone) containing $50 \mathrm{ng} / \mathrm{mL}$ human M-CSF and 50 $\mathrm{ng} / \mathrm{mL}$ human RANKL (all from R\&D Systems; Space Import-Export srl, Milano, Italy) and cultures were continued for 7 days [25].

\subsubsection{TRAP Staining}

Osteoclast formation was verified not only by the appearance of multinucleated cells but also by the positive staining with TRAP (Tartrate Resistant Acid Phosphatase) using a commercial kit (product 387-A; Sigma-Aldrich) according to manufacture' protocol. Osteoclasts were determined to be TRAP-positive staining multinucleated (>3 nuclei) cells using light microscopy. The morphological features of osteoclasts were photographed.

\subsection{Differentiation of $3 A B-O S$ Cells toward Ectodermal-Derived Cell Lineages}

\section{Neurogenic Induction}

For neural induction, 3AB-OS cells were expanded to $80 \%$ confluency in DMEM, supplemented with $10 \%$ FBS, $100 \mathrm{U} / \mathrm{ml}$ penicillin and $50 \mu \mathrm{g} / \mathrm{ml}$ streptomycin. Then, the culture medium was changed to neuronal induction media NPBM medium (Lonza Srl, Milano, Italy) supplemented with $5 \mu \mathrm{M}$ cAMP, $5 \mu \mathrm{M}$ IBMX, $25 \mathrm{ng} / \mathrm{ml}$ NGF, $2.5 \mu \mathrm{g} / \mathrm{ml}$ insulin (all from Sigma-Aldrich) for 14 days [18]. Medium was changed every 3 days for all differentiation assay. Control cultures without the differentiation stimuli were maintained in parallel to the differentiation experiments and stained in the same manner.

\subsection{Immunofluorescence Staining}

The cells were fixed with $3.7 \%$ formaldehyde for 10 min at room temperature and permeabilized with $0.1 \%$ Triton ${ }^{\circledR}$ X-100 (all from Sigma) in PBS for 5 min. After washing with PBS cells were incubated with primary antibody (diluted in PBS $+1 \% \mathrm{BSA}+0.05 \% \mathrm{NaN}_{3}$ ) at $4^{\circ} \mathrm{C}$, overnight. Cells were washed three times with PBS and incubated for $1 \mathrm{~h}$ at room temperature with secondary antibodies, which were either Cy2-conjugated or $\mathrm{Cy} 3-$ conjugated (diluted 1:100 in PBS $+1 \%$ BSA $+0.05 \%$ NaN3; Jackson ImmunoResearch Laboratories, West Grove, PA, USA). Nuclei are counterstained with 2.5 $\mu \mathrm{g} / \mathrm{ml}$ Hoechst 33342 (Sigma-Aldrich), for $10 \mathrm{~min}$. After three washes, cells were examined on a Leica DM IRB inverted microscope equipped with fluorescence optics and suitable filters for DAPI, FITC and rhodamine detection; images were photographed and captured by a computer-imaging system (Leica DC300F camera and Adobe Photoshop for image analysis). The primary antibodies are provided in Table 1.

Table 1. Antibodies used for Immunofluorescence (IF) and Western blot (WB) analyses.

\begin{tabular}{|c|c|c|}
\hline Antibody & Detection methods IF & $\begin{array}{c}\text { Detection methods } \\
\text { WB }\end{array}$ \\
\hline CD133 & - & $1 \mu \mathrm{g} / \mathrm{ml}$ \\
\hline Oct $3 / 4$ & - & $1: 300$ \\
\hline Nanog & - & $1: 300$ \\
\hline SOX2 & - & $1: 300$ \\
\hline DPPA3 & - & $1: 300$ \\
\hline NS & - & $1: 300$ \\
\hline ALP & - & $1: 300$ \\
\hline OSC & $1: 100$ & $1: 300$ \\
\hline OPN & - & $1: 300$ \\
\hline GLUT-4 & $1: 100$ & $1: 300$ \\
\hline FABP-4 & $1: 100$ & $1: 300$ \\
\hline adipsin & $1: 100$ & $1: 300$ \\
\hline VWF & $1: 100$ & - \\
\hline VGFR1 & $1: 100$ & - \\
\hline VGFR2 & $1: 100$ & - \\
\hline TNNT & $10 \mu \mathrm{g} / \mathrm{ml}$ & - \\
\hline ANP & $1: 400$ & - \\
\hline ACTN2 & $1: 100$ & - \\
\hline ALB & $10 \mu \mathrm{g} / \mathrm{ml}$ & - \\
\hline AFP & AFP & $1: 300$ \\
\hline CD49a & $1: 100$ & $1: 300$ \\
\hline CD49f & $1: 100$ & $1: 300$ \\
\hline CK18 & $1: 100$ & $1: 300$ \\
\hline CK19 & $1: 100$ & $1: 300$ \\
\hline$\beta$-catenin & $1: 100$ & $1: 500$ \\
\hline MAP-2 & $1: 100$ & $1: 300$ \\
\hline GFAP & $1: 100$ & $1: 300$ \\
\hline SYP & $1: 100$ & $1: 300$ \\
\hline $\mathrm{O} 4$ & $3 \mu \mathrm{g} / \mathrm{ml}$ & $1 \mu \mathrm{g} / \mathrm{ml}$ \\
\hline actin & - & $1: 500$ \\
\hline
\end{tabular}




\subsection{RT-PCR Analysis}

RNA was isolated using RNeasy mini kit (Qiagen, Milan, Italy). cDNA was amplified from $1 \mu \mathrm{g}$ of RNA and PCR was performed as previously reported [11]. The reactions omitting reverse transcriptase enzyme served as negative control. Actin was used as a housekeeping gene to demonstrate equal loading of RNA. The amplified products were resolved by agarose gel electrophoresis ( $1.2 \%$ agarose, $0.5 \mu \mathrm{g} / \mathrm{ml}$ ethidium bromide, Sigma) and the bands were visualized and photographed with Chemi Doc XRS (Bio-Rad Laboratories Srl, Segrate (MI), It- aly). The primers (Proligo USA, Milan, Italy) are provided in Table 2.

\subsection{Western Blot Analysis}

Cells were washed in PBS and incubated in ice-cold lysis buffer (RIPA buffer $50 \mu 1 / 10^{6}$ cells) containing protease inhibitor cocktail (Sigma-Aldrich) for $30 \mathrm{~min}$ and then sonicated three times for $10 \mathrm{~s}$. Equivalent amounts of proteins $(40 \mu \mathrm{g})$ were separated by SDS-polyacrylamide gel electrophoresis and transferred to a nitrocellulose membrane (Bio-Rad) for detection with primary anti-

Table 2. RT-PCR primer sequences.

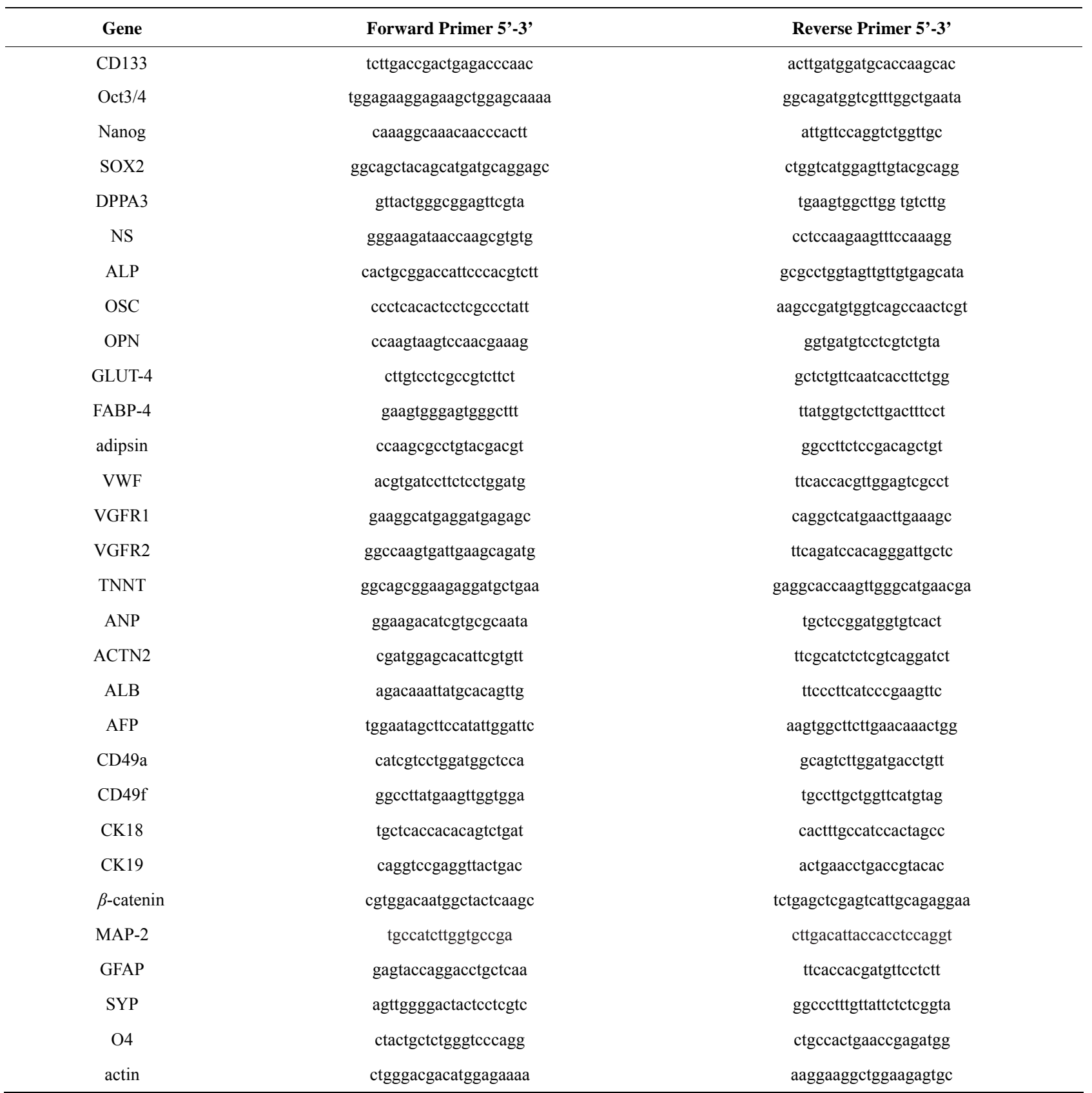


bodies and the appropriate horseradish peroxidase-conjugated secondary antibodies. Immunoreactive signals were detected using enhanced chemiluminescence (ECL) reagents (Bio-Rad). The correct protein loading was confirmed by stripping the immunoblot and reprobing with primary antibody for actin. Bands were visualized and photographed with ChemiDoc XRS (Bio-Rad). The primary antibodies are provided in Table 1.

\section{RESULTS}

Here, the human 3AB-OS cells were employed to analyse their capability to produce in vitro derivatives of the three primary germ layers (endoderm, mesoderm, ectoderm). Cells cultured in control media did not develope phenotypes derivative of any of the three germ layers (data not shown).

\subsection{Differentiation of $3 A B-O S$ Cells toward Endoderm-Derived Cell Lineages: Hepatogenic and Biliary Differentiation}

To induce hepatocyte differentiation, 3AB-OS cells were incubated into specific culture media as described in Material and Methods. Differentiation toward endodermal lineage (hepatocyte-like and biliary-like cells) occurs in two stages: 1) the initiation step, that is the commitment of the cells which entails losing the ability to differentiate into another lineage; 2) the maturation stage, that occurs as cells begin to express the phenotypic characteristics of hepatocytes.

Figures 1(A)-(D) show 3AB-OS cells cultured in media that support hepatocyte formation. During the initiation step, the heterogeneous 3AB-OS cell population (Figure 1(A)) actively proliferated reaching the confluence at the end of the fourth day (Figure 1(B)). When the induction medium was substituted with differentiation medium, at the end of the fifteenth day, 3AB-OS cells underwent visible transition from their heterogeneous, mostly fibroblastoid morphology, to a round or polygonal shape, as evidenced by the presence of hepatoblast-like oval cells mixed to cells increasingly similar to hepatocytes (Figure 1(C)). At day 20 the hepatocyte-like cells exhibited a phenotype close to that of human hepatocytes (Figure 1(D)). It is well known that glycogen synthesis, albumin production and urea secretion are characteristic features of hepatocytes. As shown in Figure 1(E), while undifferentiated $3 \mathrm{AB}-\mathrm{OS}$ cells did not secrete urea, instead differentiated cells secreted significant levels of urea. Histological evaluation by periodate acid Schiffs (PAS), shows that hepatocyte-like cells were able to store glycogen (Figure 1(F)); moreover, immunofluorescence analysis (Figure $\mathbf{1 ( G ) ) ~ s h o w s ~ a l b u m i n ~ p r o d u c t i o n ~}$ (ALB).

The same figure shows the expression of alpha-fetopro- tein (AFP), cytokeratin-18 (CK18) and alpha1-integrin (CD49a), peculiar of hepatocytes [17]. In Figure 1(H), fluorescence microscopy demonstrated fluorescein excretion (FDA), thus suggesting the presence of functional bile canaliculus-like structures.

This was also supported by the expression of cytokeratin-19 (CK19) and alpha6-integrin (CD49f) peculiar of biliary cells [17]. In Figure 1(I), Western blot (left) and RT-PCR (right) analyses confirmed hepatocyte- and biliary-like phenotype.

To further demonstrate the transition from undifferentiated into differentiated state of 3AB-OS cells, the expression of $\beta$-catenin was analyzed. As shown in Figure 1(L), western blot (left) and RT-PCR (right) analyses demonstrate that both, undifferentiated and differentiated $3 \mathrm{AB}-\mathrm{OS}$ cells had similar levels of $\beta$-catenin; however, immunofluorescence analysis evidences that while in undifferentiated cells $\beta$-catenin localization was mostly restricted to the nucleus, instead in differentiated cells $\beta$ catenin was mainly localized to the plasma membrane, thus suggesting a recruitment of $\beta$-catenin to the cell membrane with a change in its role from that of oncogene to that of structural-functional reorganization of cytoskeleton.

\subsection{Differentiation of $3 A B-O S$ Cells toward Mesoderm-Derived Cell Lineages: Osteogenic, Adipogenic, Cardiomyogenic, Angiogenic and Osteoclastogenic Differentiation}

\subsubsection{Osteogenic Differentiation}

In order to differentiate into osteoblasts, 3AB-OS cells were cultured, as described in Material and Methods, in osteogenic medium for three weeks. During this period of incubation, 3AB-OS cells morphology had a gradual change to a cuboidal shape (not shown).

At the third week (Figure 2(A)) the cells formed colonies in multiple layers, and potently stained with alkaline phosphatase (ALP), responsible for crystal formation in bone. In addition, the cells strongly acquired osteocyte like features which potently stained with Alizarin Red S (ARS), indicating mineralized matrix formation and suggesting that the putative bone cells were highly capable of calcium deposition. Immunofluorescence analysis also showed that differentiated 3AB-OS cells potently produced osteocalcin (OSC) - a bone-specific protein synthesized by osteoblasts-which represents a good marker for osteogenic maturation [19,20]. Moreover, in Figure 2(B) western blot (left) and RT-PCR (right) analyses of ALP, OSC and osteopontin (OPN, a protein which is involved in general cell attachment to the bone matrix) showed that their expression levels strongly increased after differentiation. 

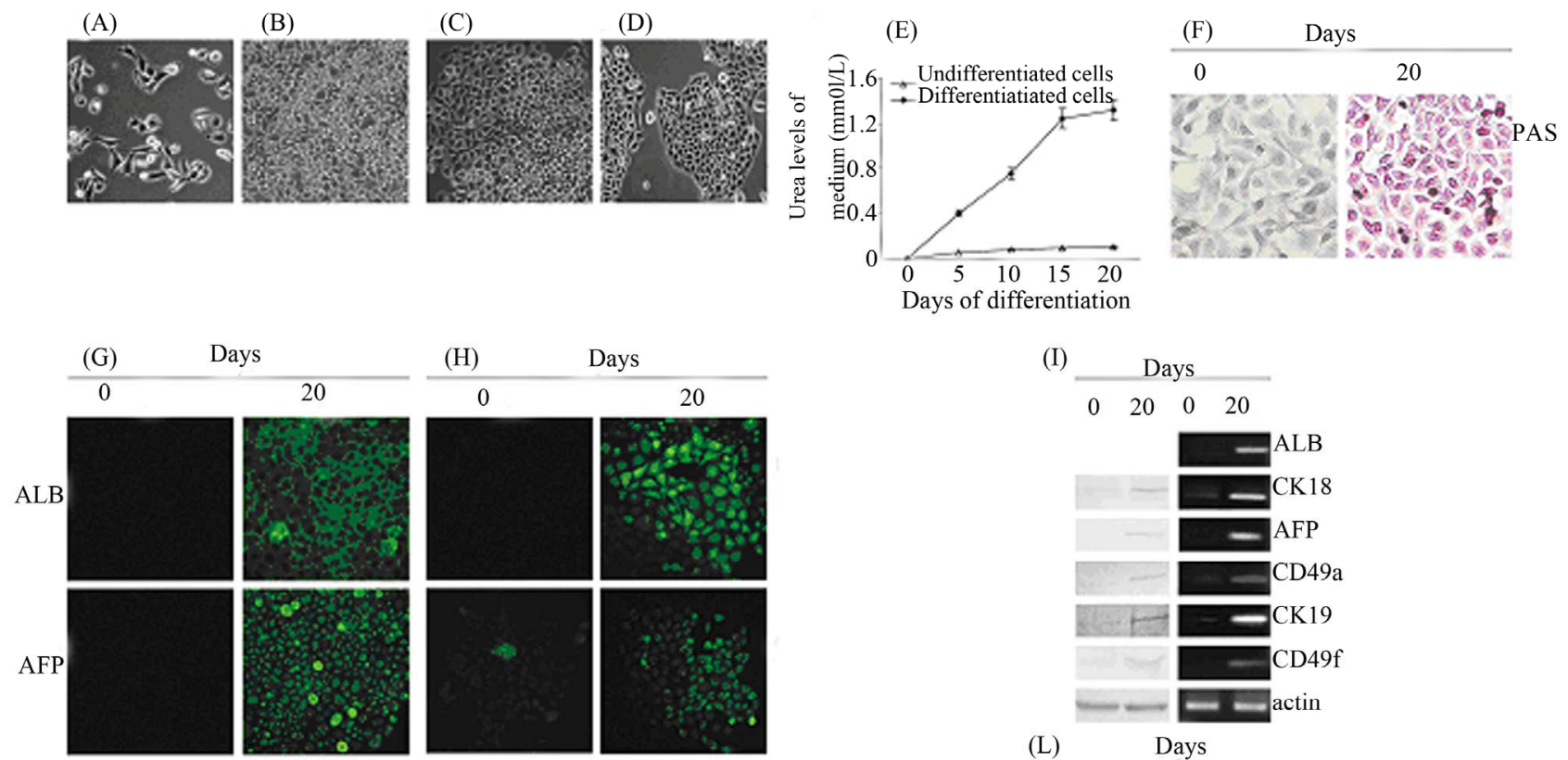

20

$\begin{array}{lll}\text { (H) } & \text { Days } & \\ 0 & & 20\end{array}$
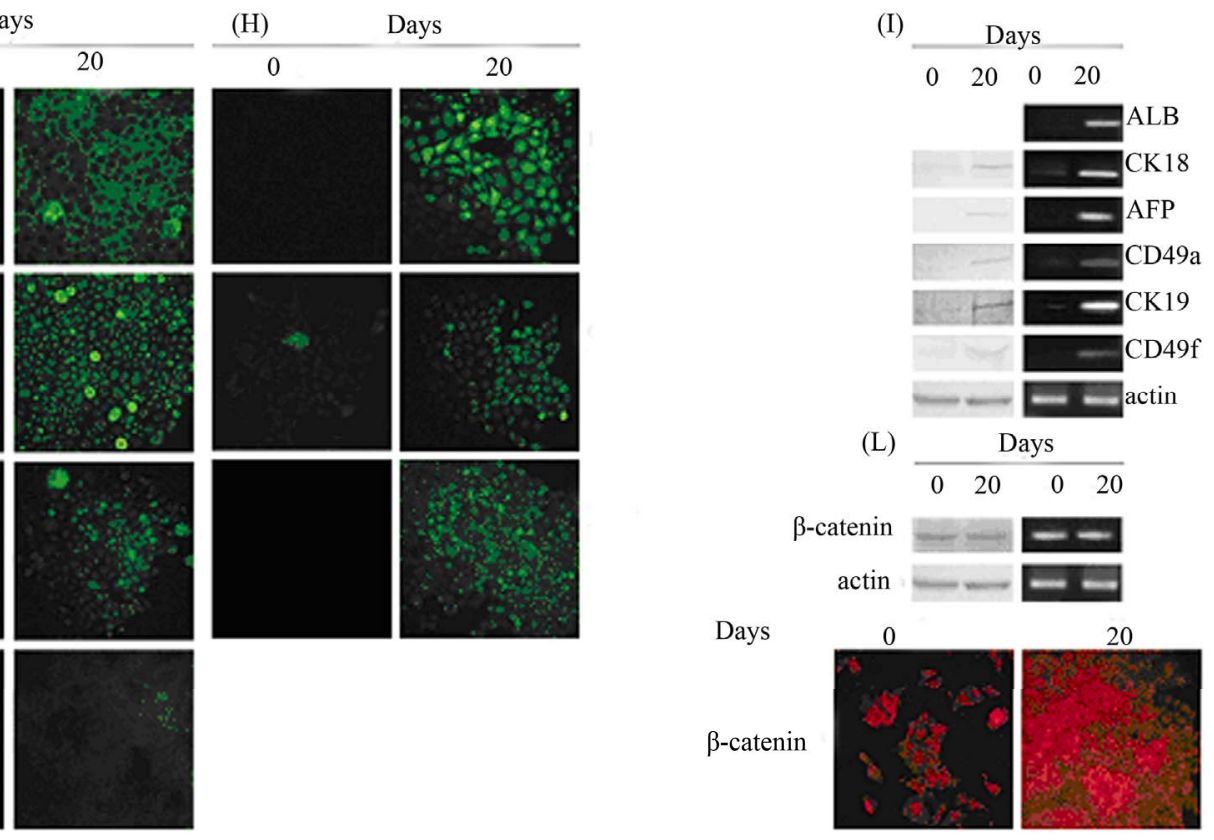

Figure 1. Differentiation of 3AB-OS cells toward endoderm-derived cell lineages: hepatogenic and biliary differentiation. (A)-(D) Changes in cell morphology of $3 \mathrm{AB}-\mathrm{OS}$ cells during hepatic differentiation (original magnification $100 \times$ ). (E) Urea secretion was assessed from both undifferentiated and differentiated $3 \mathrm{AB}-\mathrm{OS}$ cells (data are the mean $\pm \mathrm{SE}, \mathrm{n}=4$ ). (F) $3 \mathrm{AB}-\mathrm{OS}$ cells cultured in medium without hepatogenic supplements (left) did not display a positive reaction to Periodic acid-Schiff (PAS) staining, while $3 \mathrm{AB}-\mathrm{OS}$ cells cultured in hepatogenic differentiation medium (right) were positive to PAS staining, indicating accumulation of glycogen in their cytoplasm at 20 days post-induction (original magnification $200 \times$ ). (G) Immunofluorescence staining of undifferentiated ( 0 days) and differentiated (20 days) cells was performed against ALB, AFP, CK18 and CD49a (original magnification 200×). (H) Fluorescein diacetate staining (FDA) of undifferentiated ( 0 days) and differentiated (20 days) cells, suggested the presence of functional bile canaliculus-like structures. This was also supported by the expression of CK19 and CD49f (original magnification $200 \times$ ). (I) Western blot (left) and RT-PCR (right) analyses of hepatocyte and biliary markers. (L) Western blot (left), RT-PCR (right) and immunofluorescence (bottom; original magnification $200 \times$ ) analyses of $\beta$-catenin. Images are representative for at least four separate experiments. See text for the description of each abbreviation.

\subsubsection{Adipogenic Differentiation}

As described in Material and Methods, 3AB-OS cells were cultured in adipogenic medium for three weeks. Within the first two weeks of culture, cell morphology and Oil Red O staining suggested that 3AB-OS cells progressively differentiated and accumulated oil droplets in the cytoplasm (data not shown). As shown in Figure 3(A), at the third week of differentiation about $95 \%$ of $3 \mathrm{AB}-\mathrm{OS}$ cells had an adipogenic phenotype, which was evidenced under light microscopy by rounded cells and by neutral lipid-laden adipocytes and by Oil-Red O staining for lipid deposition. Immunofluorescence analyses (Figure 3(B)) evidence that differentiated cells also showed specific staining for adipocyte-related markers
[21], including glucose trasporter-4 (Glut-4), fatty acidbinding protein-4 (FABP-4) and complement factor D (adipsin), a serine protease that stimulates glucose transport for triglyceride accumulation in fats cells and inhibits lipolysis. In Figure 3(C), western blot (left) and RTPCR (right) analyses confirmed these results.

\subsubsection{Cardiomyogenic Differentiation}

$3 \mathrm{AB}-\mathrm{OS}$ cells were cultured in cardiomyogenic medium for 18 days as described in Material and Methods. In Figure 4(A) microscopy phase contrast shows that during early stages of differentiation ( 9 days), cardiomyocyte-like cells within $3 \mathrm{AB}-\mathrm{OS}$ cells were typically small and round, while nascent myofibrils were sparse 
and irregularly organized or lacking. During terminal differentiation stage (18 days), derived cardiomyocytes became elongated and densely packed bundles of myofibrils were observed. Immunofluorescence analysis also showed that more than $90 \%$ of the differentiated cells stained positive for cardiac troponin $\mathrm{T}$ (TNNT), sarcomeric alpha-actinin-2 (ACTN-2), and atrial natriuretic polypeptide (ANP). RT-PCR analysis confirmed that the expression of these cardiomyocytic-specific markers [23] were upregulated during differentiation (Figure 4(B)). However, differentiated $3 \mathrm{AB}-\mathrm{OS}$ cells lacked of spontaneous beating in culture, suggesting that the cells had not fully differentiated into mature cardiomyocytes.

\subsubsection{Angiogenic Differentiation}

Angiogenic differentiation is a very rapid process which becomes complete in seven days. As described in Material and Methods, 3AB-OS cells were cultured into the angiogenic medium after they reached $80 \%$ confluence. Although large morphological differences between differentiated and undifferentiated $3 \mathrm{AB}-\mathrm{OS}$ cells were not evidenced (Figure 5(A)), however, immunofluorescence analyses for endothelial markers [24] as Vascular Endothelial Growth Factor Receptor-1 (VEGFR1), Vascular Endothelial Growth Factor Receptor-2 (VEGFR2) and von Willebrand Factor (VWF) showed that the overall fluorescence intensity of $3 \mathrm{AB}-\mathrm{OS}$ cells potently in creased after differentiation. RT-PCR analyses confirmed
(A)

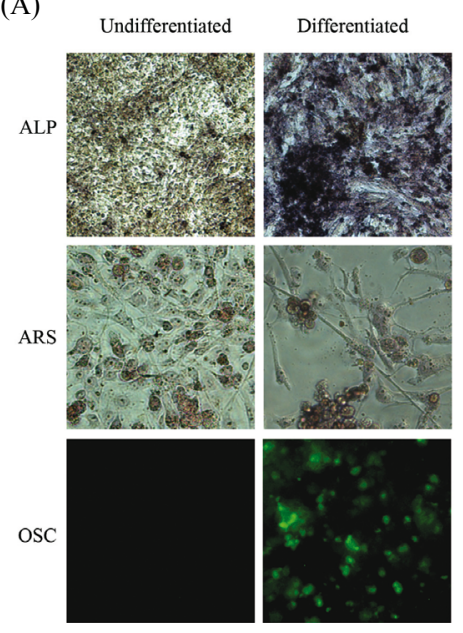

(B)

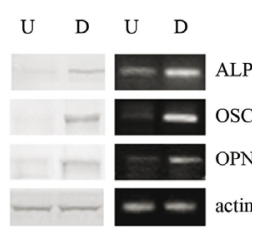

Figure 2. Differentiation of $3 \mathrm{AB}-\mathrm{OS}$ cells toward mesodermderived cell lineages: osteogenic differentiation. (A) Cells stained with Fast Red TR/Naphtol TR mixture for ALP (original magnification $100 \times$ ); with ARS for matrix mineralization (original magnification $200 \times$ ) and immunofluorescence analysis against OSC (original magnification 200×). (B) Undifferentiated (U) and differentiated (D) cells subjected to Western blot (left) and RT-PCR (right) analyses of osteogenic markers, ALP, OSC and OPN. Images are representative for at least four separate experiments. See text for the description of each abbreviation.

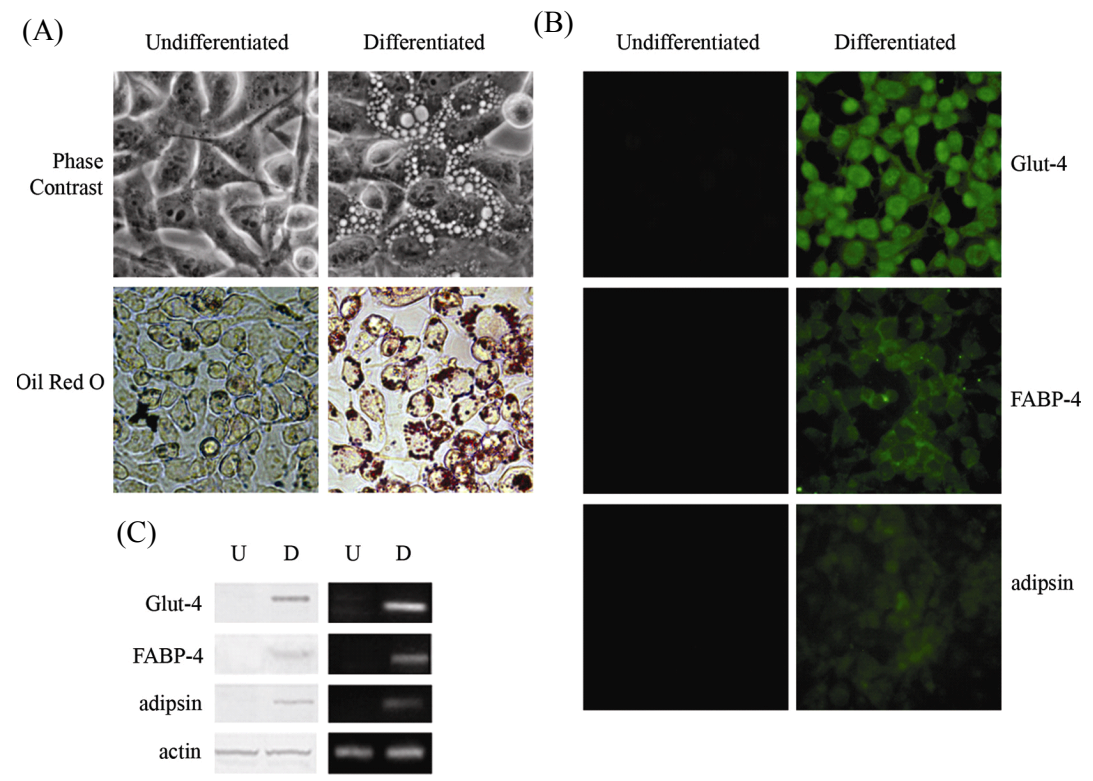

Figure 3. Differentiation of $3 \mathrm{AB}-\mathrm{OS}$ cells toward mesoderm- derived cell lineages: adipogenic differentiation. (A) Changes in cell morphology of 3AB-OS cells at the third week of differentiation. Cells stained by Oil Red $\mathrm{O}$ for detection of lipid formation (original magnification $400 \times$ for all figures). (B) Immunofluorescence analyses against Glut-4, FABP-4 and adipsin (original magnification 200×). (C) Undifferentiated (U) and differentiated (D) cells subjected to Western blot (left) and RT-PCR (right) analyses of adipogenic markers. Images are representative for at least four separate experiments. See text for the description of each abbreviation. 


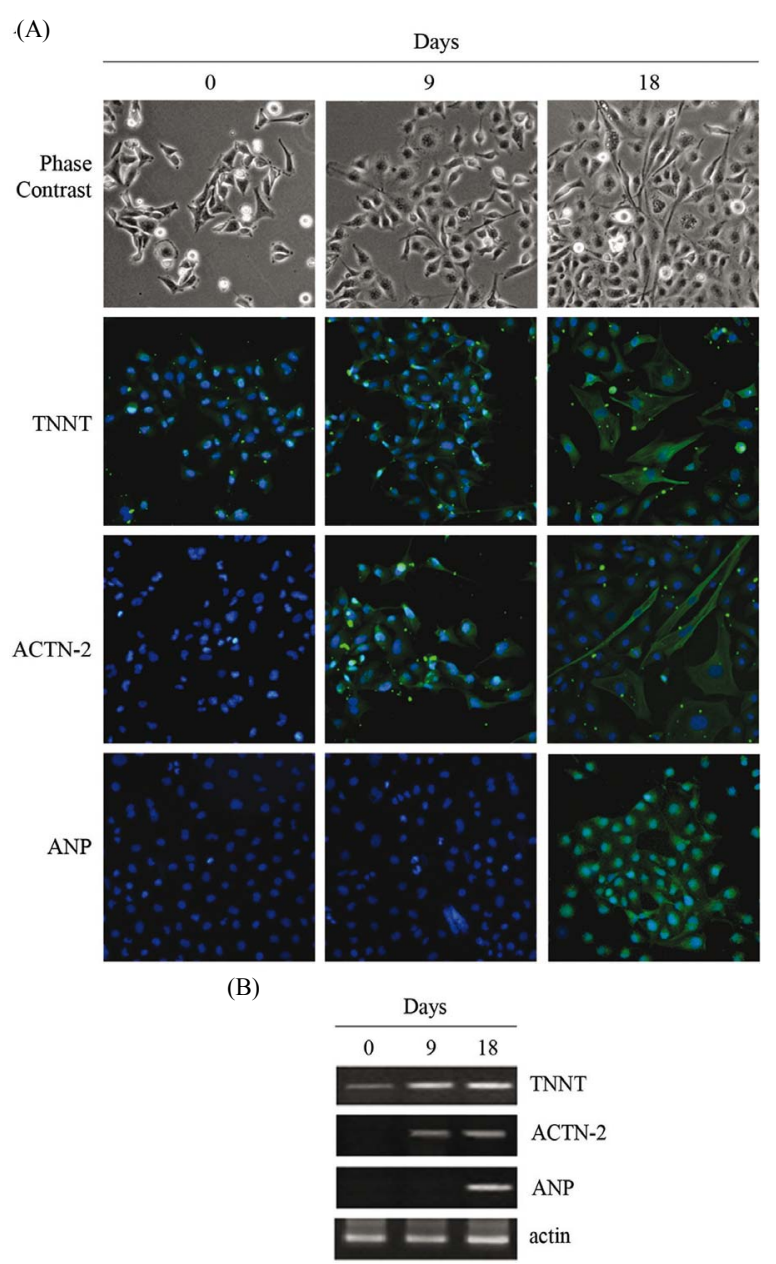

Figure 4. Differentiation of $3 \mathrm{AB}-\mathrm{OS}$ cells toward mesoderm-derived cell lineages: cardiomyogenic differentiation. (A) Changes in cell morphology of $3 \mathrm{AB}-\mathrm{OS}$ cells during cardiomyogenic differentiation (0 - 18 days; original magnification $100 \times$ ). Cells stained for TNNT, ACTN-2 and ANP; nuclei counterstained with Hoechst 33342 (original magnification 200×). (B) RT-PCR analysis of cardiomyogenic markers. Images are representative for at least four separate experiments. See text for the description of each abbreviation.

these results (Figure 5(B)). The ability of 3AB-OS cells to form capillaries in semisolid medium was assessed using the EC matrix in vitro angiogenesis kit. To this purpose, $3 \mathrm{AB}-\mathrm{OS}$ cells were seeded on the top of the ECmatrix gel solution and cultivated either in the presence or absence of VEGF. As shown in Figure 5(C), after 24 hours in culture, 3AB-OS cells formed capillarylike structures in the presence or absence of VEGF.

\subsubsection{Osteoclastogenic Differentiation}

Even osteoclast differentiation is a very rapid process which become complete in seven days. Under the influence of the differentiation and maturation factors described in Material and Methods, 3AB-OS cells progres- sively differentiate (Figure 6(A)) until reaching mature osteoclasts, characterized by the presence of multiple nuclei and by the basal ruffled, invadent border (Figure 6(B)). It is well known that osteoclasts express some specific markers, such as tartrate resistant acid phosphatase (TRAP) and cathepsin K (CTSK) [26]. In Figure 6(C), in agreement with osteoclast morphology, light microscopy shows that differentiated $3 \mathrm{AB}-\mathrm{OS}$ cells are highly positive for TRAP-staining. In addition, RT-PCR analysis shows the expression of the CTSK gene (Figure 6(D)).

\subsection{Differentiation of 3AB-OS Cells toward Ectodermal-Derived Cell Lineages: Neurogenic and Gliogenic Differentiation}

When 3AB-OS cells were cultured in the neurogenic medium described in Material and Methods, after an initial time (three days) during which cell actively proliferated (Figure 7(A)), a large number of cells died and a mixing of neuron-like and glial-like cells appeared (Figure 7(B)). After 15 days in differentiation medium, cells with small cell body and elongated thin processes (characteristic of neurons) were observed (Figure 7(C)), while other cells, with large cell body and several thick and thin processes (characteristic of astrocytes, Figure 7(D) or oligodendrocyte-like cells, Figure 7(E)) were observed. Interestingly, after 25 days in culture, when differentiation appeared to be completed, cells appeared to be covered by a thick matrix which looked like extracellular matrix (Figure 7(F)). By immunofluorescence analyses (Figure 7(G)) differentiated 3AB-OS cells showed specific staining for neuron markers (micro-tubule-associated protein 2 (MAP-2) and synaptophysin (SYP)), for astrocyte-marker (glial fibrillary acid protein (GFAP)) and for oligodendrocyte markers (O4) [18,27,28]. Neuronal, astrocytic, and oligodendrocytic markers expression was also shown by western blot (left) and RT-PCR (right) analyses (Figure 7(H)).

\subsection{Evaluation of Stem Cell Marker Levels during Differentiation}

Previously we have shown that $3 \mathrm{AB}-\mathrm{OS}$ cells express a number of pluripotent markers as Oct3/4, Nanog, nucleostemin (NS), and CD133 [13]. Here, we show that $3 \mathrm{AB}-\mathrm{OS}$ cells also express two other markers of pluripotency, SOX2 and DPPA3 $[29,30]$. All these markers have been checked after each derived cell lineage by western blot (left) and RT-PCR (right) analyses (Figure 8). As shown in the Figure, undifferentiated $3 \mathrm{AB}-\mathrm{OS}$ cells strongly expressed all the pluripotency markers tested, while in differentiated cells these markers were profoundly downregulated. 


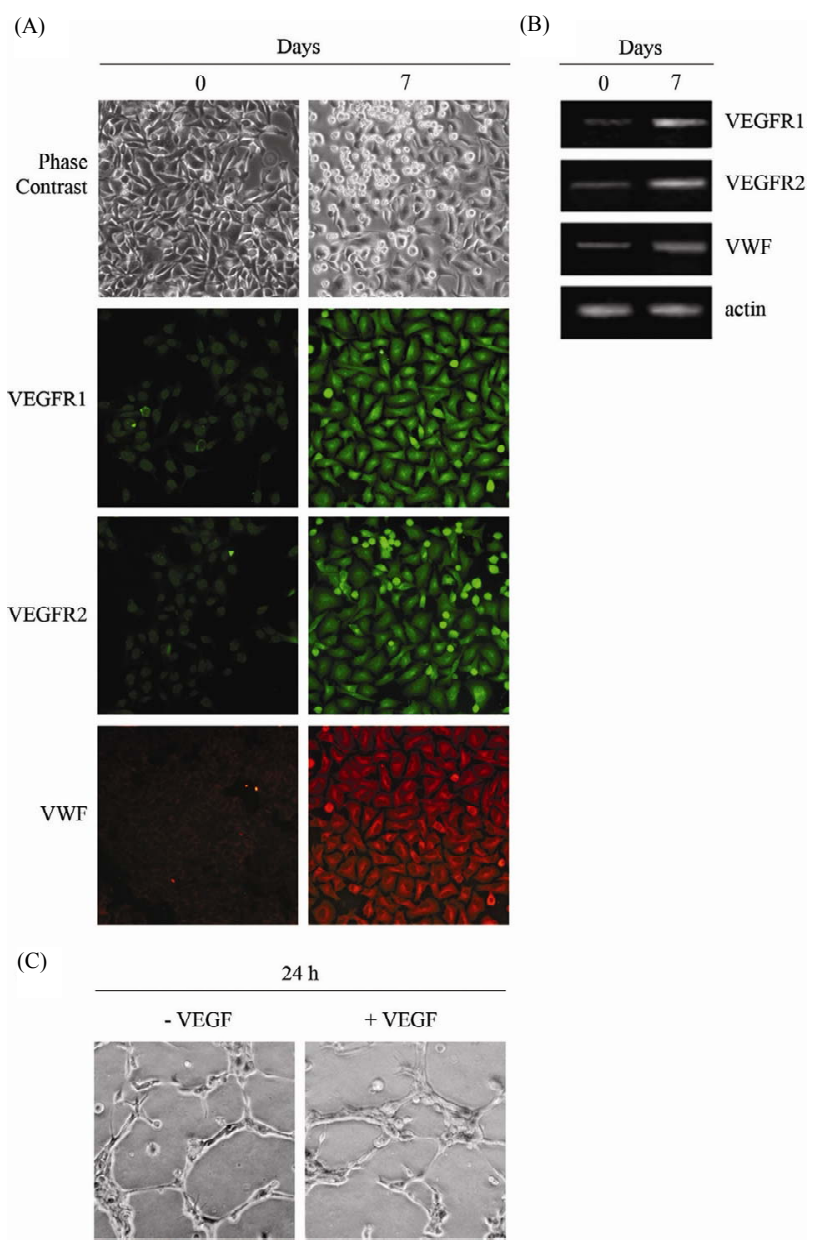

Figure 5. Differentiation of $3 \mathrm{AB}-\mathrm{OS}$ cells toward mesodermderived cell lineages: angiogenic differentiation. (A) Morphologic analyses of undifferentiated ( 0 days) and differentiated (7 days) $3 \mathrm{AB}-\mathrm{OS}$ cells (original magnification $100 \times$ ); immunofluorescence analyses for the endothelial markers VEGFR1, VEGFR2 and VWF (Original magnification 200×). (B) RTPCR analysis of endothelial markers. (C) Light microscopy of capillary-like structures originated from $3 \mathrm{AB}-\mathrm{OS}$ cells in the absence and presence of VEGF (original magnification 200×). Images are representative for at least four separate experiments. See text for the description of each abbreviation.

\section{DISCUSSION}

Cancer is a major public health problem, which profoundly affects both industrialized and developing countries. Despite the decline in US cancer incidence and mortality rates, cancer remains the number one cause of death for people under the age of 85 , and one in four people in the US will die of cancer, mainly because of metastasis [31]. The number of people affected by various types of cancer continues to grow and according to World Health Organization cancer statistics, 15 million people worldwide are expected to have cancer (excluding skin cancer) by 2015 .

It is well known that CSCs are cells that possess the
(A)

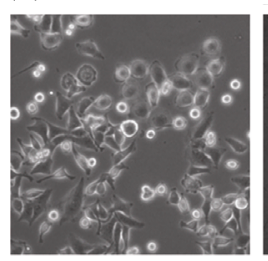

(B)

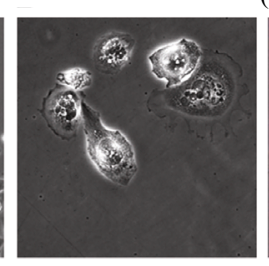

(C)

(D)

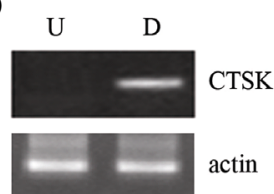

Figure 6. Differentiation of $3 \mathrm{AB}-\mathrm{OS}$ cells toward mesoderm-derived cell lineages: osteoclast differentiation. (A) Morphology of $3 \mathrm{AB}-\mathrm{OS}$ cells before differentiation (original magnification $100 \times$ ) and (B) after seven days differentiation (original magnification $200 \times$ ). (C) Differentiated cells subjected to the TRAP assay (original magnification 200×). (D) Undifferentiated (U) and differentiated (D) cells subjected to RT-PCR analysis of CTSK gene. Images are representative for at least four separate experiments. See text for the description of each abbreviation.

capacity to self-renew and to give rise to the heterogeneous lineages of cancer cells that comprise the tumor, which can self-renew and undergo asymmetrical divisions, giving rise to a differentiated progeny that represents most of the tumor populations [32]. CSCs also possess the ability for prolonged survival, angiogenesis, and high resistance to chemotherapy and radiotherapy, which could explain the high frequency of neoplasia relapse years after apparently eradicating therapies [5]. These cells are also equipped to metastasize, invade and colonize secondary tissues with instructive cues to maintain themselves being generated by both intrinsic and niche microenvironment networks [33]. Thus, to better understand the mechanisms that govern malignant disease progression, the isolation and characterization of CSCs for each cancer type is an urgent need. Whether CSCs derive from transformed stem cells or result from cancer cells during their progressive development is still an open question [34], however the cancer stem cell field has stimulated lots of interest in the world and has ushered in a new era of cancer research. Understanding the mechanism which drives CSCs proliferation, invasion and differentiation will have fundamental clinical implications for cancer risk assessment, early detection, prognostication, prevention and therapy and might change the landscape of cancer biology. Thus, the winning goal in cancer research would be to find some vulnerability that will enable scientists to kill both cancer cells and cancer stem cells, while sparing cells needed for normal functioning. Although research in this area is bursting, much remains to be learned about these unique cells, and un- 
(A)
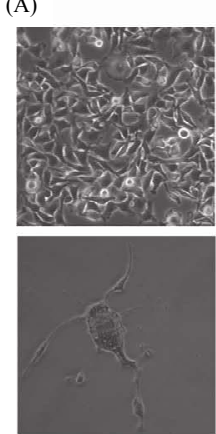

(D)
(B)
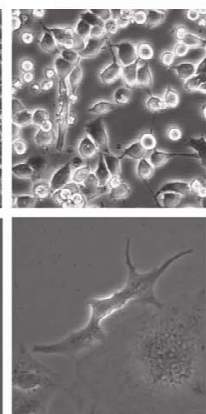

(E)
(C)
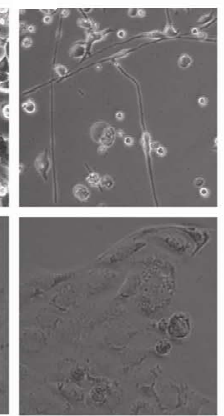

(F)
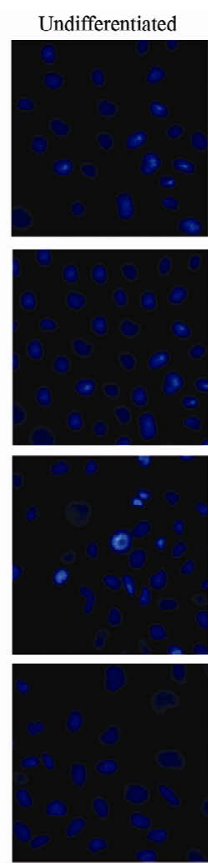

Differentiated
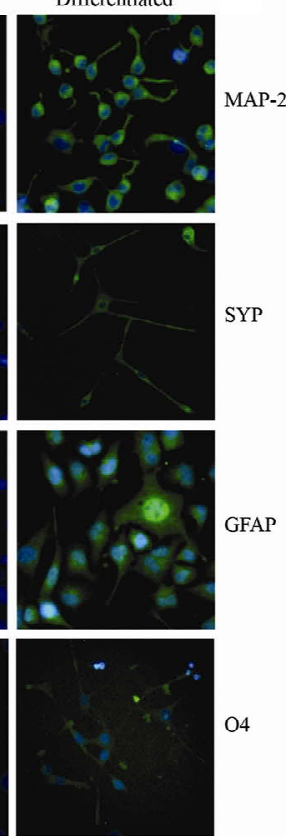

Figure 7. Differentiation of $3 \mathrm{AB}-\mathrm{OS}$ cells toward ectodermal-derived cell lineages: neurogenic and gliogenic differentiation. (A)-(F) Changes in cell morphology of 3AB-OS cells during neurogenic differentiation $((A)(C)$ original magnification $100 \times$; (B) (D) (E) (F) original magnification $200 \times)$. (G) Immunofluorescence staining of $3 \mathrm{AB}-\mathrm{OS}$ cells against MAP-2, SYP, GFAP and O4; nuclei counterstained with Hoechst 33342 (original magnification $200 \times$ ). (H) Undifferentiated (U) and differentiated (D) cells subjected to Western blot (left) and RT-PCR (right) analyses of neuronal, astrocytic and oligodendrocytic markers. Images are representative for at least four separate experiments. See text for the description of each abbreviation.

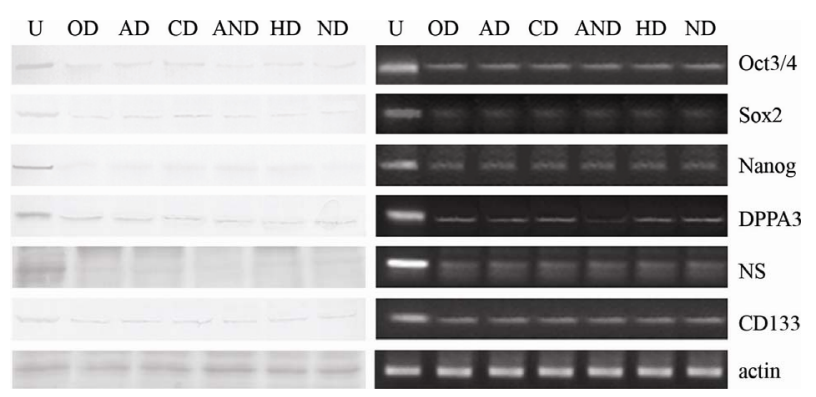

Figure 8. Evaluation of stem cell markers. Undifferentiated (U) and differentiated (see below the abbreviations for derived cell lineages) 3AB-OS cells subjected to Western blot (left) and RT-PCR (right) analyses of stem cell markers Oct3/4, SOX2, Nanog, DPPA3, NS and CD133. Images are representative for at least four separate experiments. Abbreviations: Osteogenic Differentiation (OD); Adipogenic Differentiation (AD); Cardiomyogenic Differentiation (CD); Angiogenic Differentiation (AND); Hepatogenic Differentiation (HD); Neurogenic Differentiation (ND).

derstanding the shared and distinguishing mechanisms that drive cancer cell propagation and normal stem cell proliferation will address versus molecular pathways that are triggered in carcinogenesis, thereby providing researchers and clinicians with additional targets to allevi- ate the burden of cancer. It has been observed that cellular signaling pathways that regulate normal stem cells are often deregulated in human cancers $[35,36]$.

Previously, we have genetically and molecularly characterized 3AB-OS CSCs, and employing bioinformatic analyses, we have selected 196 genes and 46 anticorrelated miRNAs involved in carcinogenesis and stemness. For the first time, we have described a predictive network for two miRNA family (let-7/98 and miR-29a,b,c) and their anticorrelated mRNAs (MSTN, CCND2, Lin28B, MEST, HMGA2 and GHR), which may represent new biomarkers for osteosarcoma and may pave the way for the identification of new potential therapeutic targets [14].

We have also shown that $3 \mathrm{AB}-\mathrm{OS}$ cells are strongly tumorigenic in vivo where they recapitulated various features of human osteosarcoma [15]. Here, we investigated $3 \mathrm{AB}-\mathrm{OS}$ pluripotency, studying the capability to produce in vitro derivatives of all the three primary germ layers. The results showed that $3 \mathrm{AB}-\mathrm{OS}$ cells can differentiate into endoderm-, mesoderm- and ectoderm-derived lineages. Cell differentiation was morphological, molecular and functional. As regards endoderm-derived cell lineages, 3AB-OS cells formed hepatic and biliary-like 
cells which produced ALB, stored glycogen, formed functional bile canaliculus-like structures and expressed a large number of hepatic and biliary cell markers. As regards mesoderm-derived cell lineages $3 \mathrm{AB}-\mathrm{OS}$ cells were capable of osteogenic, adipogenic, cardiomyogenic, angiogenic and osteoclastogenic differentiation. Indeed, they formed colonies in multiple layers which strongly acquired osteocyte-like features and potently stained for ALP and ARS and produced OSC and OPN; they produced neutral lipid-laden adipocytes which strongly stained for lipid deposition, Glut-4, FABP-4 and adipsin; $3 \mathrm{AB}-\mathrm{OS}$ cells also produced typically elongated cardiomyocyte-like cells with densely packed bundles of myofibrils which strongly stained for TNNT, ACTN-2 and ANP; they efficiently formed capillary-like structures and expressed high levels of VEGFR1, VEGFR2 and VWF; they formed mature osteoclasts with multiple nuclei and a basal ruffled border which strongly expressed TRAP and CTSK. As regards ectoderm-derived cell lineages, 3AB-OS cells produced a large number of neuronal-, astrocyte-, and oligodendrocyte-like cells which stained for neuron markers (MAP-2 and SYP), astrocytemarker (GFAP) and oligodendrocyte marker (O4). Interestingly, neuron and glial-like cells were progressively covered by a thick extracellular-like matrix which suggested a mechanism of completion of the differentiation process. Moreover, each of the differentiated cell lineage obtained showed a profound downregulation of the pluripotency markers expressed by $3 \mathrm{AB}-\mathrm{OS}$ cells. We do not know what is the reason why the cancer stem cells, such as normal stem cells, have the ability to differentiate toward the derivatives of the primary germ layers. It is well known that to sustain growth and survival in their hostile microenvironment, rapidly growing tumors have to overcome hypoxia and a lack of nutrients through angiogenesis [37]. Thus, it is possible that each of the differentiation capability may be exploited by CSCs to supply their needs of growing and surviving in hostile microenvironment. For example, it is possible that the ability of 3AB-OS CSCs to efficiently form capillary-like structures could be a way for them to put their pluripotency at the service of their need of growing and invading. Overall, we propose that this model system of 3ABOS differentiation in vitro might have a number of useful purposes, among which their use to study the molecular mechanisms of osteosarcoma origin, to define the factors that are involved in specification of the various cell lineages. Moreover, 3AB-OS could be used to produce, after their engineering, protein pharmaceuticals. Pluripotent stem cells offer the possibility of a renewable source of replacement cells and tissues to treat a myriad of diseases, conditions and disabilities [38-41]. We still do not know which are the differences between normal stem cells (SCs) and CSCs. It is thought that stem cells live within microscopic protective "niches," which would be responsible for their features, namely their dormant status, their low metabolic rate with low growth factor requirement and their long life living. Although stem cells enter the cell cycle only rarely, however, when they do, they have the potential to regenerate the entire tissue. They also possess defense mechanisms against chemical and toxic insults and strong response systems against DNA damage. Overall, these characters protect stem cells from accumulating mutations that may occur during cell divisions. As both cancer cells and CSCs are characterized by the accumulation of a large number of mutations, it is possible that the main difference among SCs and CSCs is the loss of niche control. The characteristics of CSCs therefore does not imply that their potential application to treat clinical conditions will result in tumor formation. We still do not know whether differentiation of 3AB-OS cells is or not a reversible process. Thus, about their hoped clinic use, there are a number of answers that still we need to do.

\section{ACKNOWLEDGEMENTS}

This study was supported by grants from Italian Ministry of Education, University and Research (MIUR) ex-60\%, 2007; MIUR-PRIN; contract number 2008P8BLNF (2008); MIUR; contract number 867/ 06/07/2011; MIUR; contract number 2223/12/19/2011; MIUR-PRIN; contract number 144/01/26/2012.

\section{REFERENCES}

[1] Tang, N., Song, W.X., Luo, J., Haydon, R.C. and He, T.C. (2008) Osteosarcoma development and stem cell differentiation. Clinical Orthopaedics and Related Research, 8 2114-2130. doi:10.1007/s11999-008-0335-Z

[2] Ta, H.T., Dass, C.R., Choong, P.F. and Dunstan, D.E. (2009) Osteosarcoma treatment: State of the art. Cancer and Metastasis Reviews, 28, 247-263. doi:10.1007/s10555-009-9186-7

[3] Mirabello, L., Pfeiffer, R., Murphy, G., Daw, N.C., Patiño-Garcia, A., Troisi, R.J., Hoover, R.N., Douglass, C., Schüz, J., Craft, A.W. and Savage, S.A. (2011) Height at diagnosis and birth-weight as risk factors for osteosarcoma. Cancer Causes \& Control, 22, 899-908. doi:10.1007/s10552-011-9763-2

[4] Wesolowski, R. and Budd, G.T. (2010) Use of chemotherapy for patients with bone and soft-tissue sarcomas. Cleveland Clinic Journal of Medicine, 77, S23-S26. doi:10.3949/ccjm.77.s1.05

[5] Clevers, H. (2011) The cancer stem cell: Premises, promises and challenges. Nature Medicine, 17, 313-319. doi: $10.1038 / \mathrm{nm} .2304$

[6] Li, L. and Neaves, W.B. (2006) Normal stem cells and cancer stem cells: The niche matters. Cancer Research, 66, 4553-4557. doi:10.1158/0008-5472.CAN-05-3986

[7] Maitland, N.J. and Collins, A.T. (2008) Prostate cancer 
stem cells: A new target for therapy. Journal of Clinical Oncology, 26, 2862-2870.

doi:10.1200/JCO.2007.15.1472

[8] Frank, N.Y., Schatton, T. and Frank, M.H. (2010) The therapeutic promise of the cancer stem cell concept. Journal of Clinical Investigation, 120, 41-50. doi:10.1172/JCI41004

[9] Morrison, R., Schleicher, S.M., Sun, Y., Niermann, K.J., Kim, S., Spratt, D.E., Chung, C.H. and Lu, B. (2011) Targeting the mechanisms of resistance to chemotherapy and radiotherapy with the cancer stem cell hypothesis. Journal of Oncology, 2011, 13 p. doi:10.1155/2011/941876

[10] Prud'homme, G.J. (2012) Cancer stem cells and novel targets for antitumor strategies. Current Pharmaceutical Design, 18, 2838-2849. doi:10.2174/138161212800626120

[11] De Blasio, A., Musmeci, M.T., Giuliano, M., Lauricella, M., Emanuele, S., D'Anneo, A., Vassallo, B., Tesoriere, G. and Vento, R. (2003) The effect of 3-aminobenzamide, inhibitor of poly(ADP-ribose) polymerase, on human osteosarcoma cells. International Journal of Oncology, 23, 1521-1528.

[12] De Blasio, A., Messina, C., Santulli, A., Mangano, V., Di Leonardo, E., D'Anneo, A., Tesoriere, G. and Vento, R. (2005) Differentiative pathway activated by 3-aminobenzamide, an inhibitor of PARP, in human osteosarcoma MG63 cells. FEBS Letters, 579, 615-620. doi:10.1016/i

[13] Di Fiore, R., Santulli, A., Ferrante, R.D., Giuliano, M., De Blasio, A., Messina, C., Pirozzi, G., Tirino, V., Tesoriere, G. and Vento, R. (2009) Identification and expansion of human osteosarcoma-cancer-stem cells by long-term 3aminobenzamide treatment. Journal of Cellular Physiology, 219, 301-313. doi:10.1002/jcp.21667

[14] Di Fiore, R., Fanale, D., Drago-Ferrante, R., Chiaradonna, F., Giuliano, M., De Blasio, A., Amodeo, V., Corsini, L.R., Bazan, V., Tesoriere, G., Vento, R. and Russo, A. (2012). Genetic and Molecular Characterization of the human osteosarcoma $3 \mathrm{AB}-\mathrm{OS}$ cancer stem cell line: A possible model for studying osteosarcoma origin and stemness. Journal of Cellular Physiology, 228, 1189-1201. doi: $10.1002 /$ jep. 24272

[15] Di Fiore, R., Guercio, A., Puleio, R., Di Marco, P., Drago-Ferrante, R., D’Anneo, A., De Blasio, A., Carlini, D., Di Bella, S., Pentimalli, F., Forte, I.M., Giordano, A., Tesoriere, G. and Vento, R. (2012). Modeling human osteosarcoma in mice through $3 \mathrm{AB}-\mathrm{OS}$ cancer stem cell xenografts. Journal of Cellular Biochemestry, 113, 33803392. doi: $10.1002 /$ jcb. 24214

[16] Wei, X., Wang, C.Y., Liu, Q.P., Li, J., Li, D., Zhao, F.T., Lian, J.Q., Xie, Y.M., Wang, P.Z., Bai, X.F. and Jia, Z.S. (2008) In vitro hepatic differentiation of mesenchymal stem cells from human fetal bone marrow. The Journal of International Medical Research, 36, 721-727. doi:10.1177/147323000803600414

[17] Cerec, V., Glaise, D., Garnier, D., Morosan, S., Turlin, B., Drenou, B., Gripon, P., Kremsdorf, D., Guguen-Guillouzo, C. and Corlu, A. (2007) Transdifferentiation of hepatocyte-like cells from the human hepatoma HepaRG cell line through bipotent progenitor. Hepatology, 45, 957-967. doi:10.1002/hep.21536

[18] Tondreau, T., Lagneaux, L., Dejeneffe, M., Massy, M., Mortier, C., Delforge, A. and Bron, D. (2004) Bone marrow-derived mesenchymal stem cells already express specific neural proteins before any differentiation. Differentiation, 72, 319-326. doi:10.1111/j.1432-0436.2004.07207003.x

[19] Park, B.W., Hah, Y.S., Kim, D.R., Kim, J.R. and Byun, J.H. (2007) Osteogenic phenotypes and mineralization of cultured human periosteal-derived cells. Archives of Oral Biology, 52, 983-989. doi:10.1016/j.archoralbio.2007.04.007

[20] Post, S., Abdallah, B.M., Bentzon, J.F. and Kassem, M. (2008) Demonstration of the presence of independent preosteoblastic and pre-adipocytic cell populations in bone marrow-derived mesenchymal stem cells. Bone, 43, 3239. doi:10.1016/j.bone.2008.03.011

[21] Mauney, J.R., Volloch, V. and Kaplan, D.L. (2005) Matrix-mediated retention of adipogenic differentiation potential by human adult bone marrow-derived mesenchymal stem cells during ex vivo expansion. Biomaterials, 26, 6167-6175. doi:10.1016/i.biomaterials.2005.03.024

[22] Ilancheran, S., Michalska, A., Peh, G., Wallace, E.M., Pera, M. and Manuelpillai, U. (2007) Stem cells derived from human fetal membranes display multilineage differentiation potential. Biology of Reproduction, 77, 577-588. doi:10.1095/biolreprod.106.055244

[23] Shim, W.S., Jiang, S., Wong, P., Tan, J., Chua, Y.L., Tan, Y.S., Sin, Y.K., Lim, C.H., Chua, T., The, M., Liu, T.C. and Sim, E. (2004) Ex vivo differentiation of human adult bone marrow stem cells into cardiomyocyte-like cells Biochemical and Biophysical Research Communications, 324, 481-488. doi:10.1016/i.bbrc.2004.09.087

[24] Oswald, J., Boxberger, S., Jørgensen, B., Feldmann, S., Ehninger, G., Bornhäuser, M. and Werner, C. (2004) Mesenchymal stem cells can be differentiated into endothelial cells in vitro. Stem Cells, 22, 377-384. doi:10.1634/stemcells.22-3-377

[25] Yen, M.L., Tsai, H.F., Wu, Y.Y., Hwa, H.L., Lee, B.H. and Hsu, P.N. (2008) TNF-related apoptosis-inducing ligand (TRAIL) induces osteoclast differentiation from monocyte/macrophage lineage precursor cells. Molecular Immunology, 45, 2205-2213. doi:10.1016/i.molimm.2007.12.003

[26] Ljusberg, J., Wang, Y., Lång, P., Norgård, M., Dodds, R., Hultenby, K., Ek-Rylander, B. and Andersson, G. (2005) Proteolytic excision of a repressive loop domain in tartrate-resistant acid phosphatase by cathepsin $\mathrm{K}$ in osteoclasts. The Journal of Biological Chemistry, 280, 2837028381. doi:10.1074/jbc.M502469200

[27] Kerr, C.L., Letzen, B.S., Hill, C.M., Agrawal, G., Thakor, N.V., Sterneckert, J.L., Gearhart, J.D. and All, A.H. (2010) Efficient differentiation of human embryonic stem cells into oligodendrocyte progenitors for application in a rat contusion model of spinal cord injury. International Journal of Neuroscience, 120, 305-313. doi: $10.3109 / 00207450903585290$

[28] Tarsa, L. and Balkowiec, A. (2009) Nerve growth factor regulates synaptophysin expression in developing trige- 
minal ganglion neurons in vitro. Neuropeptides, 43, 47-52. doi:10.1016/j.npep.2008.09.009

[29] Yu, J., Vodyanik, M.A., Smuga-Otto, K., AntosiewiczBourget, J., Frane, J.L., Tian, S., Nie, J., Jonsdottir, G.A., Ruotti, V., Stewart, R., Slukvin, I.I. and Thomson, J.A. (2007) Induced pluripotent stem cell lines derived from Human Somatic Cells. Science, 318, 1917-1920. doi:10.1126/science. 1151526

[30] Clark, A.T., Rodriguez, R.T., Bodnar, M.S., Abeyta, M.J., Cedars, M.I., Turek, P.J., Firpo, M.T. and Reijo Pera, R.A. (2004) Human STELLAR, NANOG, and GDF3 genes are expressed in pluripotent cells and map to chromosome 12p13, a hotspot for teratocarcinoma. Stem Cells, 22, 169-179. doi:10.1634/stemcells.22-2-169

[31] Reagan, M.R. and Kaplan, D.L. (2011) Concise review: Mesenchymal stem cell tumor-homing: Detection methods in disease model systems. Stem Cells, 29, 920-927. doi:10.1002/stem.645

[32] Clarke, M.F., Dick, J.E., Dirks, P.B., Eaves, C.J., Jamieson, C.H., Jones, D.L., Visvader, J., Weissman, I.L. and Wahl, G.M. (2006) Cancer stem cells-perspectives on current status and future directions: AACR Workshop on cancer stem cells. Cancer Research, 66, 9339-9344. doi:10.1158/0008-5472.CAN-06-3126

[33] Heddleston, J.M., Hitomi, M., Venere ,M., Flavahan, W.A., Yang, K., Kim, Y., Minhas, S., Rich, J.N. and Hjelmeland, A.B. (2011) Glioma stem cell maintenance: The role of the microenvironment. Current Pharmaceutical Design, 17, 2386-2401. doi:10.2174/138161211797249260

[34] Bapat, S.A. (2007) Evolution of cancer stem cells. Se- minars in Cancer Biology, 17, 204-213. doi:10.1016/j.semcancer.2006.05.001

[35] Mikhail, S. and He, A.R. (2011) Liver cancer stem cells. International Journal of Hepatology, 2011, Article ID: 486954. doi:10.4061/2011/486954

[36] Valkenburg, K.C., Graveel, C.R, Zylstra-Diegel, C.R., Zhong, Z. and Williams, B.O. (2011) Wnt/ $\beta$-catenin Signaling in normal and cancer stem cells. Cancers, 3, 2050 2079. doi: $10.3390 /$ cancers3022050

[37] Park, J.E., Tan, H.S., Datta, A., Lai, R.C., Zhang, H., Meng, W., Lim, S.K. and Sze, S.K. (2010) Hypoxic tumor cell modulates its microenvironment to enhance angiogenic and metastatic potential by secretion of proteins and exosomes. Molecular \& Cellular Proteomics, 9, 10851099. doi:10.1074/mcp.M900381-MCP200

[38] Rashid, S.T. and Lomas, D.A. (2012) Stem cell-based therapy for $\alpha_{1}$-antitrypsin deficiency. Stem Cell Research and Therapy, 3, 4. doi:10.1186/scrt95

[39] Sanal, M.G. (2011) Future of liver transplantation: Nonhuman primates for patient-specific organs from induced pluripotent stem cells. World Journal of Gastroenterology, 17, 3684-3690. doi:10.3748/wjg.v17.i32.3684

[40] Barrero, M.J. and Izpisua Belmonte, J.C. (2011) iPS cells forgive but do not forget. Nature Cell Biology, 13, 523525. doi:10.1038/ncb0511-523

[41] Odorico, J.S., Kaufman, D.S. and Thomson, J.A. (2001) Multilineage differentiation from human embryonic stem cell lines. Stem Cells, 19, 193-204. doi:10.1634/stemcells.19-3-193 